Bull. Chem. Soc. Ethiop. 2020, 34(3), 501-521.

ISSN 1011-3924

(c) 2020 Chemical Society of Ethiopia and The Authors

Printed in Ethiopia

DOI: https://dx.doi.org/10.4314/bcse.v34i3.7

\title{
NICOTINE METAL COMPLEXES: SYNTHESIS, CHARACTERIZATION AND BIOACTIVITIES OF SOME MAIN GROUP AND SOME TRANSITION METALS
}

\author{
Nasser S. Awwad ${ }^{1}$, Hala A. Ibrahium ${ }^{2,3}$, Ali A. Shati ${ }^{4}$, Mohammad Y. Alfaifi ${ }^{4}$ and Yi-Hsu Ju ${ }^{5}$, \\ and Ahmed E. Fazary ${ }^{6,7^{*}}$
}

${ }^{1}$ Department of Chemistry, King Khalid University, P.O. Box 9004, Abha 61413, Saudi Arabia

${ }^{2}$ Research Center for Advanced Materials Science (RCAMS), King Khalid University, Abha 9004, Abha 61413, Saudi Arabia

${ }^{3}$ Department of Semi Pilot Plant, Nuclear Materials Authority, P.O. Box 530, El Maadi, Egypt

${ }^{4}$ Department of Chemistry, King Khalid University, P.O. Box 9004, Abha 61413, Saudi Arabia

${ }^{5}$ Yi-Hsu Ju -Graduate Institute of Applied Science and Technology, Department of Chemical

Engineering, Taiwan Building Technology Center, National Taiwan University of Science and Technology, 43 Section 4, Keelung Road, Taipei 10607, Taiwan

${ }^{6}$ Applied Research Department, Research and Development Sector, Egyptian Organization for Biological Products and Vaccines (VACSERA Holding Company), 51 Wezaret El-Zeraa St., Agouza, Giza, Egypt

${ }^{7}$ National Committee for Pure and Applied Chemistry (NCPAC 2018-2022), Academy of

Scientific Research and Technology (ASRT), 110 Al Kasr Al Aini, El-Sayeda Zainab, Cairo Governorate 11334, Egypt

(Received January 15, 2020; Revised November 20, 2020; Accepted December 10, 2020)

\begin{abstract}
A number of some main group and transition metal nicotine complexes were synthesized and fully characterized using detailed structural and spectroscopic analysis techniques such as elemental analysis, molar conductivities, magnetic susceptibilities, IR, Raman and NMR techniques. Moreover, scanning electron micrographs and thermogravimetric analyses were also done. Cytotoxic activities of the binary nicotine metal complexes were tested and evaluated against HepG2 (human hepatocellular carcinoma), HPC3 (human prostate cancer), and HCT116 (human colorectal carcinoma) tumor cell lines. The antioxidant activities were examined by free radical scavenging assay. The antimicrobial activities of the synthesized complexes were evaluated against Escherichia coli (gram-negative) and Staphylococcus aureus (gram-positive) microbes. The relationship between the chemical structure of the synthesized complexes and their biological influence as antimicrobial drugs was studied and evaluated.
\end{abstract}

KEY WORDS: Nicotine metal complexes, Cytotoxicity, Antioxidant, Antimicrobial

\section{INTRODUCTION}

Nicotine (3-((2S)-1-methylpyrrolidin-2-yl)pyridine, Scheme 1) is a bicyclic chiral alkaloid with a pyridine and a pyrrolidine cycles, possessing an asymmetric carbon and existing as two enantiomeric compounds (Scheme 1). Naturally, nicotine only exists in the $\mathrm{S}$ shape and is found in Solanaceae night shade family plants such as Nicotiana rustica, Nicotiana tabacum, Duboisia hopwoodii and Asclepias syriaca [1]. It functions as a potent parasympathomimetic, stimulant drug, antiherbivore chemical, antagonist, nicotinic acetylcholine receptor agonist, insecticide and it is widely used as highly addictive unless used in slow-release forms [2-4].

By searching in the literature survey, a number of crystal structures of metal complexes of nicotine had been previously prepared and their three-dimensional structures were elucidated using single crystal X-ray crystallography technique [5-26]. In most of these structures, nicotine acts a monodentate ligand, coordinated via the pyridine nitrogen [5-26]. The quantum-

*Corresponding author. E-mail: aefazary@gmail.com

This work is licensed under the Creative Commons Attribution 4.0 International License 
mechanical calculations provided information on the energetic of the possible interaction modes of copper(II), zinc(II), and cobalt(II) chiral supramolecular metal complexes of (S)-(-)-nicotine [5-26]. Novel metal $\mathrm{La}(\mathrm{II}), \operatorname{Pr}(\mathrm{III}), \mathrm{Nd}(\mathrm{IV})$, palladium(II), and mercury(II) complexes of nicotine were synthesized and their plausible chemical structures were exhaustively characterized using X-ray diffraction, circular dichroism, and nuclear magnetic resonance spectroscopic methods [5-26]. At present, there is a tendency in searching for anticancer substances in natural sources are usually supposed to be fewer toxic and produce negligible side possessions. Medications from ordinary sources have been used conventionally for thousands of ages in many places of the world. Experts have embattled numerous traditional or common drugs in similar of contemporary medicine to recognize and extract vigorous ingredients for the medication development.

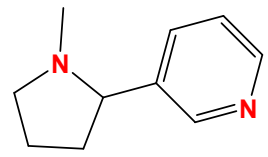

Scheme 1. Chemical structure of nicotine (NIC).

Research interest on the interactions of bioactive ligands with different metal ions have been increased during the last decade in my laboratory [27-41]. Recently, the experimental protonation and complex formation equilibrium constants of nicotine (NIC) with trivalent (iron(III), and chromium(III)) and divalent (copper(II), and nickel(II)) metal ions have been investigated in aqueous solutions using $\mathrm{pH}$-potentiometric, and cyclic voltammetry techniques [42]. In the present work, a number of binary nicotine complexes were synthesized and fully characterized using detailed structural and spectroscopic analysis techniques. The cytotoxic activities of the binary nicotine metal complexes were tested and evaluated against some tumor cell lines. The antioxidant activities were examined by free radical scavenging assay. As well, the antimicrobial assay was done against Escherichia coli (gram-negative) and Staphylococcus aureus (gram-positive). The relationship between the chemical structure of the synthesized complexes and their biological influence as antimicrobial drugs was studied and evaluated.

\section{EXPERIMENTAL}

Synthesis of binary metal - nicotine complexes

A series of different binary nicotine complexes were synthesized according to the following general procedure: an methanolic solution $(20 \mathrm{~mL})$ of different metal salts $(0.1 \mathrm{M})$ was added gradually to methanolic solution $(20 \mathrm{~mL})$ of nicotine (NIC $(0.2 \mathrm{M})$, and stirred carefully and refluxed at $185^{\circ} \mathrm{C}$ for $6 \mathrm{~h}$ till the reaction was completed. Dehydrated the product by placing the resulting reaction mixture into a fume cupboard, leading to the isolation of solid precipitated complex products. Later they were filtered off, washed thoroughly with diethyl ether and ethanol mixture several times to remove any traces of unreacted starting materials and finally dried in a vacuum desiccator over fused $\mathrm{CaCl}_{2}$. Yield: $35-55 \%$. For the binary nicotine (NIC) complexes, the preparation ratios $\left(\mathrm{T}_{\mathrm{L}}: \mathrm{T}_{\mathrm{M}}=2: 1, \mathrm{~L}=\right.$ nicotine (NIC), $\mathrm{M}$ (metal ion)).

Physical measurements of the synthesized nicotine complexes

Elemental analyses (carbon, hydrogen and nitrogen) of the binary complexes were performed on a Thermo Scientific TM Flash 2000 Series CHNS/O Analyzer at Precision Instrumentation Center, College of Science, National Taiwan University, Taipei, Taiwan. Melting points of all 
the binary complexes were determined in open glass capillaries and were recorded on a Fisher Johns melting point apparatus. A Digital Elico Conductivity Bridge meter (Model No. CM-180) was used to measure the molar conductance of the free ligands and the metal binary complexes in DMSO solutions with a concentration of about $1 \times 10^{-3} \mathrm{M}$ at room temperature, using a diptype conductivity cell fitted with a platinum electrode. Magnetic susceptibility measurements of the powdered binary complexes were measured at room temperature with a Magway MSBMk1 magnetic susceptibility balance using $\mathrm{Hg}\left[\mathrm{Co}(\mathrm{NCS})_{4}\right]$ as the calibrant. Magnetic measurements were carried out according to the Gauy method. The calculations were evaluated by applying the following equations (1-3):

$x_{g}=\frac{c l\left(R-R_{O}\right)}{10^{9} M}$

$x_{m}=x_{g} M W_{t}$

$\mu_{\text {eff }}=2.828 \sqrt{ } x_{m} T$

where $x$ is mass susceptibility per $\mathrm{g}$ of sample; $c$ is the calibration constant; $R$ is the balance reading for the sample and tube; $R_{0}$ is the balance reading for the empty tube; $M$ is the weight of the sample in $\mathrm{g}$. The metal content of the complexes was determined by a Buck Scientifics 210VGP Atomic Absorption Spectrophotometer.

Spectroscopic and structural measurements of the synthesized nicotine complexes

Vibration infrared spectral (IR) studies of all synthesized binary metal nicotine (NIC) complexes were recorded on a Shimadzu FT-IR 8000 spectrophotometer using $\mathrm{KBr}$ disc medium in the range $400-4000 \mathrm{~cm}^{-1}$ and the spectra were collected with a resolution of $2 \mathrm{~cm}^{-1}$ with 15 scans. The proton ${ }^{1} \mathrm{H}$ NMR and ${ }^{13} \mathrm{C}$ NMR spectra of the binary complexes were recorded on a JEOL GSX $400 \mathrm{MHz}$ FT-NMR spectrometer employing TMS as internal reference to $0.0 \mathrm{ppm}$, and DMSO- $\mathrm{d}_{6}$ as solvent with a field gradient operating at $500.13 \mathrm{MHz}$ for proton observation, and the measurements were done at a probe temperature of about $298 \mathrm{~K}$. Fast atomic bombardment mass spectra (FAB-MS) of nicotine (NIC), and their metal complexes were recorded on a JEOL SX-102 FAB mass spectrometer using 3-nitrobenzoyl alcohol matrix. Scanning electron microscope (SEM) images were obtained using a JEOL JEM-1200 EX II Electron microscope at an acceleration voltage of $25 \mathrm{kV}$. Micro-Raman Spectrometer analysis system (Raman RS2000) with laser source (wavelength $=532 \mathrm{~nm}$ ) at UniNanoTech/UniD2G (National Taiwan University of Science and Technology) was used to analyze the synthesized solid complexes. Thermogravimetric analysis (TGA) and differential thermal analysis (DTA) measurements of the binary complexes were conducted using Shimadzu (DSC-50 model) thermal analyzer in dynamic nitrogen atmosphere at a flow rate of $20 \mathrm{~mL} \mathrm{~min}^{-1}$ with a heating rate of $20^{\circ} \mathrm{C} / \mathrm{min}$ starting from room temperature to $1000{ }^{\circ} \mathrm{C}$.

Cytotoxic and antioxidant activities

Cytotoxic and antioxidant behavior of NIC and its synthesized complexes were in vitro assayed and quantitative estimated statistically using SPSS 17.0 statistical software package as done previously in our recent published work based on the experimental measurements used for quantitative analysis that were repeated at least three times [27].

Antimicrobial assay

The potency of nicotine metal complexes as antimicrobial agent was tested against a gram positive microorganism Staphylococcus aureus and a gram negative microorganism Escherichia 
coli. Broth macro-dilution method was used for the determination of inhibitory activity of the complex. Ampicilin $\left(895.5 \mu \mathrm{g} \cdot \mathrm{mL}^{-1}\right.$ potency) was used as the antibiotic reference. The complex was prepared at 3 concentrations $\left(100,1000\right.$ and $\left.2000 \mu \mathrm{g} \cdot \mathrm{mL}^{-1}\right)$. The complex with the best inhibitory activity was then tested further to determine the minimal inhibition concentration $\left(\mathrm{MIC}_{50}\right.$ and $\left.\mathrm{MIC}_{90}\right)$. The assay was performed in a tube containing the tested compound dissolved in Lysogeny Broth (LB) media which was prepared from the mixture of tryptone, yeast extract and sodium chloride with a ratio of 2:1:2 w/w/w. Fifteen micro-liters of the prepared bacteria suspension $\left(1 \times 10^{8} \mathrm{cfu} \cdot \mathrm{mL}^{-1}\right)$ were injected to the test tube. After incubated for $24 \mathrm{~h}$ at $37{ }^{\circ} \mathrm{C}$, the $\mathrm{OD}_{600 \mathrm{~nm}}$ of each sample was measured. As the growth control, $15 \mu \mathrm{L}$ of bacteria suspension was injected into the test tube containing no sample. The antimicrobial activity was expressed as \%inhibition as shown in the following equation:

$\%$ inhibition $=([\mathrm{Ic}-\mathrm{Is}] / \mathrm{Ic}) \times 100$

where (Ic) is the absorbance of control and (Is) is the absorbance of sample at $600 \mathrm{~nm}$.

\section{RESULTS AND DISCUSSION}

\section{Physical and chemical characterizations}

Different metal - NIC binary complexes have a reported melting points ranging from $270{ }^{\circ} \mathrm{C}$ to $31{ }^{\circ} \mathrm{C}$. The molar conductivity values for the synthesized complexes $\left(1.0 \times 10^{-3} \mathrm{~mol} / \mathrm{cm}^{3}\right)$ were found between 57 and $98 \Omega^{-1} \mathrm{~cm}^{2} \mathrm{~mol}^{-1}$ suggesting a moderate electrolytic nature, and provide a method of testing the degree of ionization of the complexes. These results were strongly supported by the elemental analysis data. The magnetic susceptibilities $\left(\mu_{\text {effe }}\right)$ of the synthesized complexes at room temperature were found to be consistent with low spin distorted octahedral structures. The elucidation molecular structures of the synthesized nicotine complexes were confirmed by detailed spectroscopic IR, Raman and NMR techniques. The synthesized complexes were found to be stable at room temperature with different colors, and partially soluble in $\mathrm{D}_{2} \mathrm{O}$, soluble in DMSO and DMF solvents. The proposed coordination modes of the resulted complexes are dependent on the routine spectral analysis.

\section{Infrared and NMR spectral analysis}

The essential infrared and Raman spectral absorption patterns of the synthesized complexes are shown in Figures 1, 2 and 3. Careful inspection of the IR spectra of free nicotine (NIC) ligand and its synthesized binary complexes was made in order to facilitate the assignment of these bands in the free ligand and its metal complexes as shown in the IR charts. It was concluded that there is no straight regularity in the change of wavenumbers of the analyzed bands along with the position of the nitrogen atom in the aromatic ring. That means, electronic charge distribution of the whole molecule differs depending on the position of the nitrogen in the ring in the presence of metal ions. The nuclear magnetic resonance ${ }^{1} \mathrm{H}$ NMR and ${ }^{13} \mathrm{C}$ NMR spectra of free nicotine (NIC) ligand and its synthesized metal complexes recorded in DMSO- $\mathrm{d}_{6}$ taking TMS as internal standards could be found in Figures 4 and 5. From the proton and carbon assignments for the free nicotine (NIC) ligand and its synthesized metal complexes, the comparison between peaks of free ligand and their complexes appeared clearly, in which there are blue shifted in the assignments values of protons and carbons because of the metal-ligand complex formation.

\section{Scanning electron microscope (SEM) analysis}

The scanning electron micrographs (SEM) at various magnifications of the synthesized binary metal-nicotine complexes show the layered structure, surface morphology, and microstructure of 
the studied complexes as in the typical scanning electron micrographs shown in Figure 6 . The surface morphology of SEM micrograph reveals the well sintered nature of the complexes with variant grain sizes and shapes. The distribution of grain size is homogeneous for most complexes, and it is clear that very small grains are obtained with agglomerates for different $\mathrm{Fe}(\mathrm{III}), \mathrm{Cu}(\mathrm{II}), \mathrm{Bi}(\mathrm{II}), \mathrm{Ni}(\mathrm{II})$, and $\mathrm{Zn}(\mathrm{II})$ complexes of nicotine (NIC). The particle size distribution of all synthesized complexes was evaluated and the average particle sizes of these were obtained.
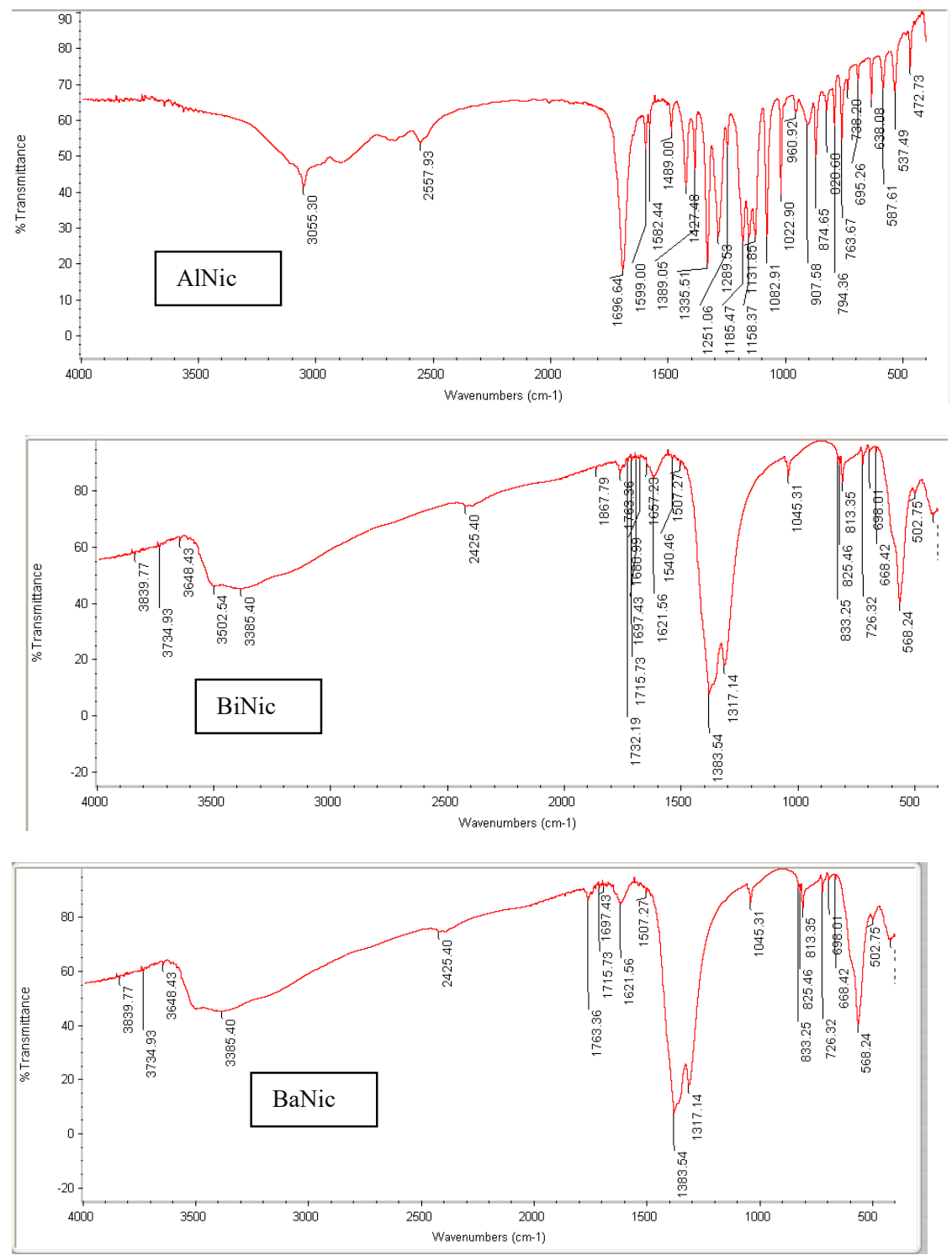

Bull. Chem. Soc. Ethiop. 2020, 34(3) 


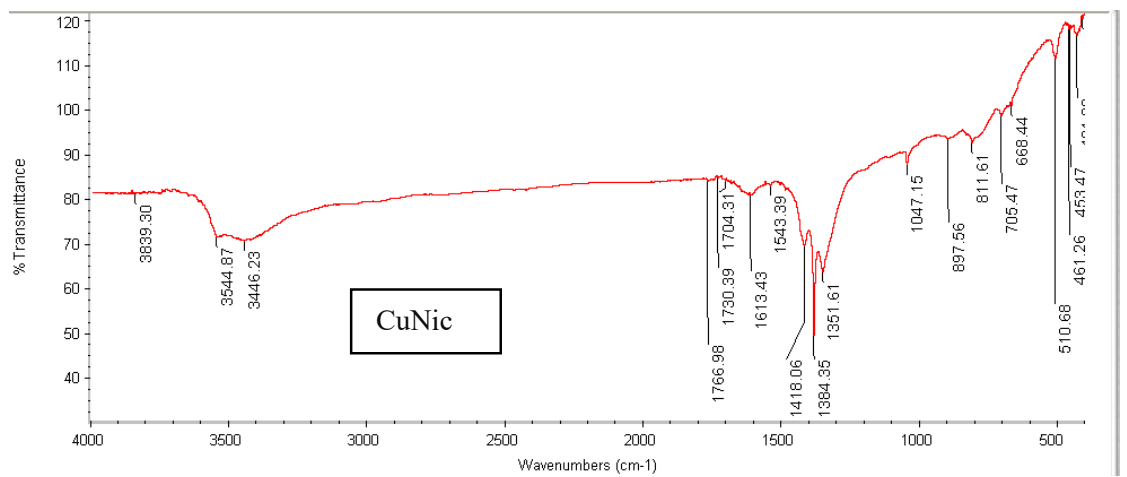

Figure 1. IR Spectral data of AlNic, BiNic, BaNic, and CuNic binary complexes.
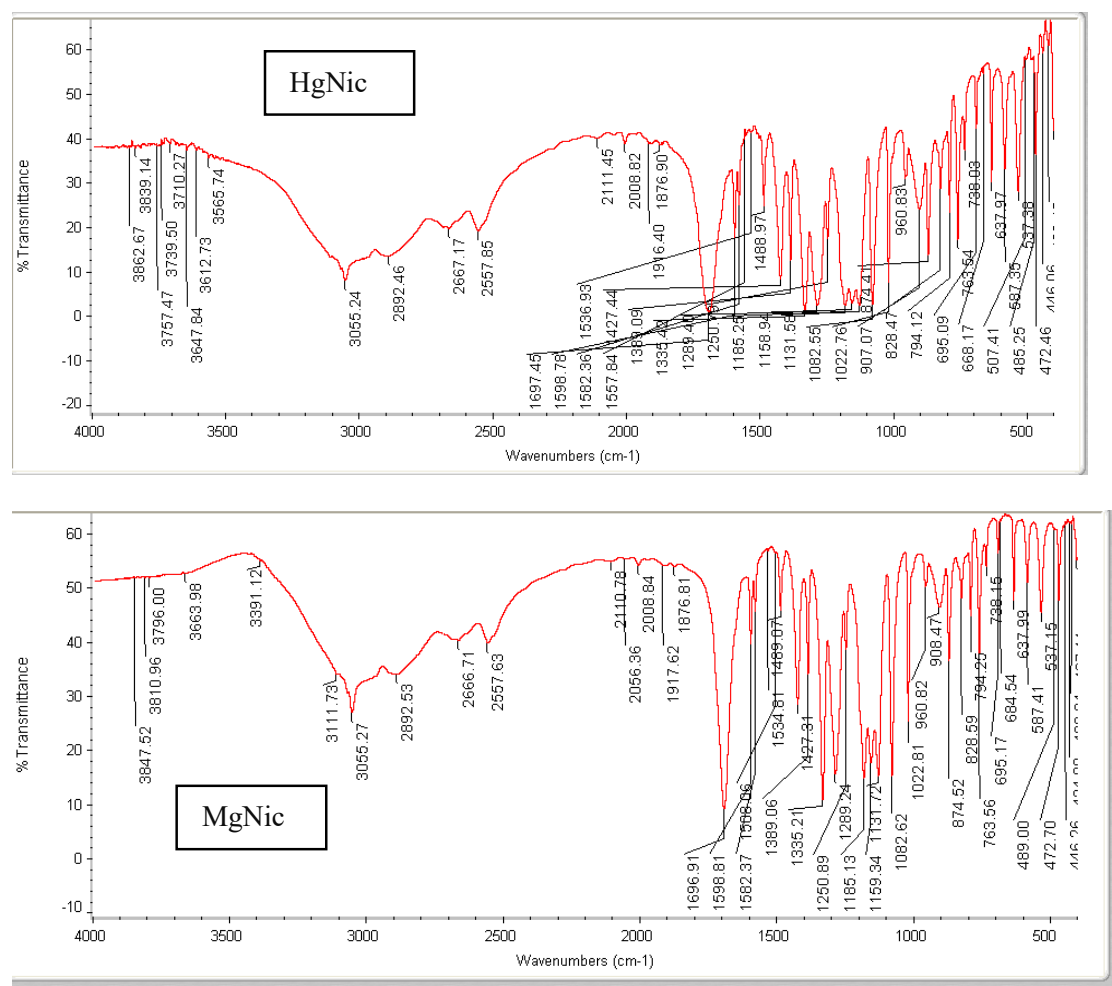

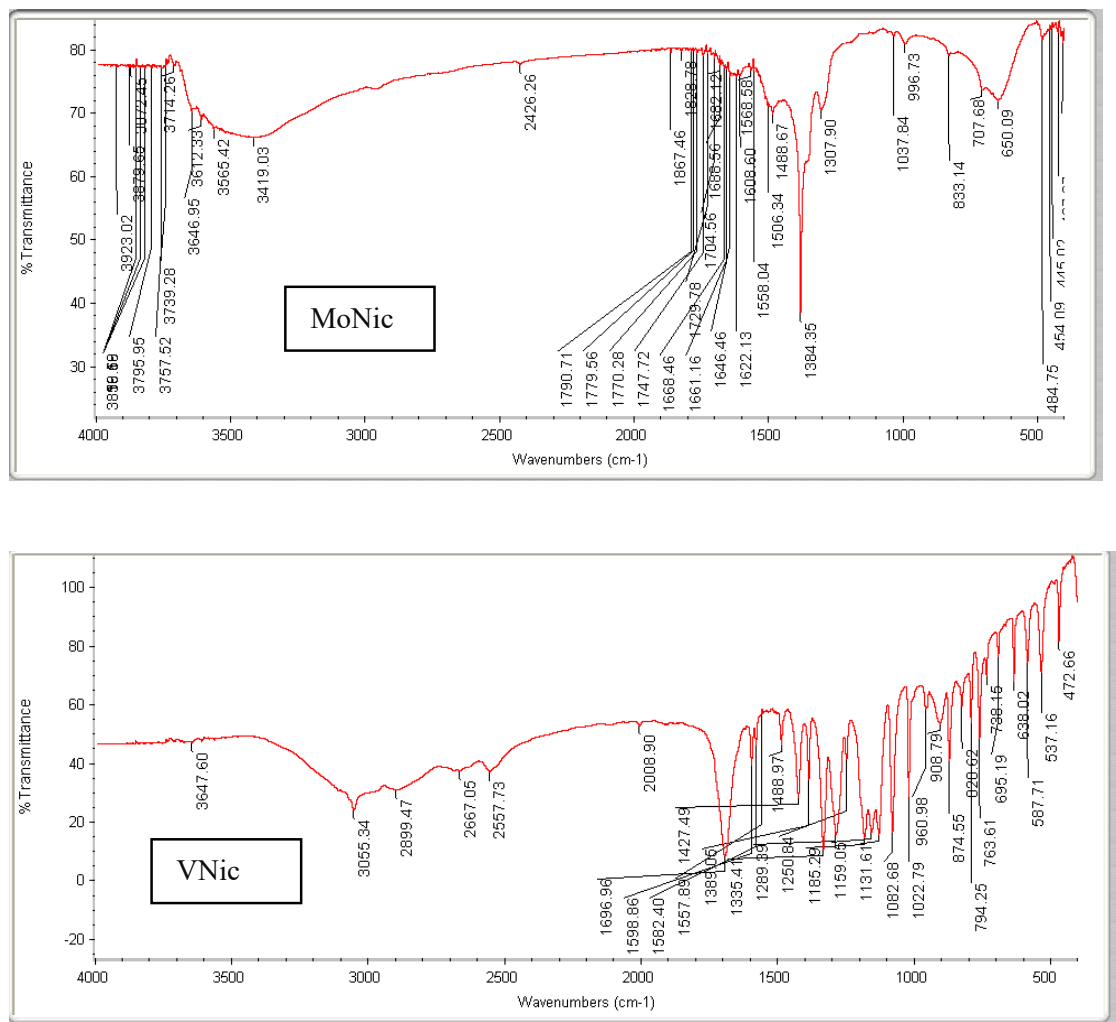

Figure 2. IR Spectral data of $\mathrm{HgNic}, \mathrm{MgNic}, \mathrm{MoNic}$, and VNic binary complexes.

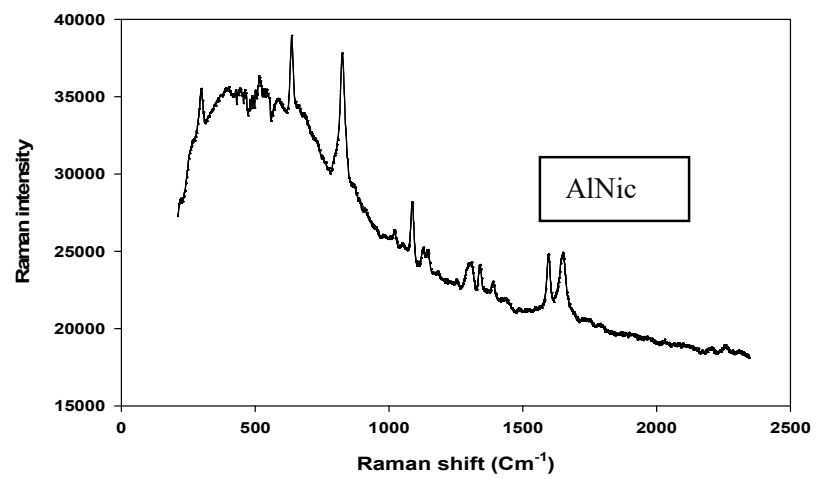

Bull. Chem. Soc. Ethiop. 2020, 34(3) 

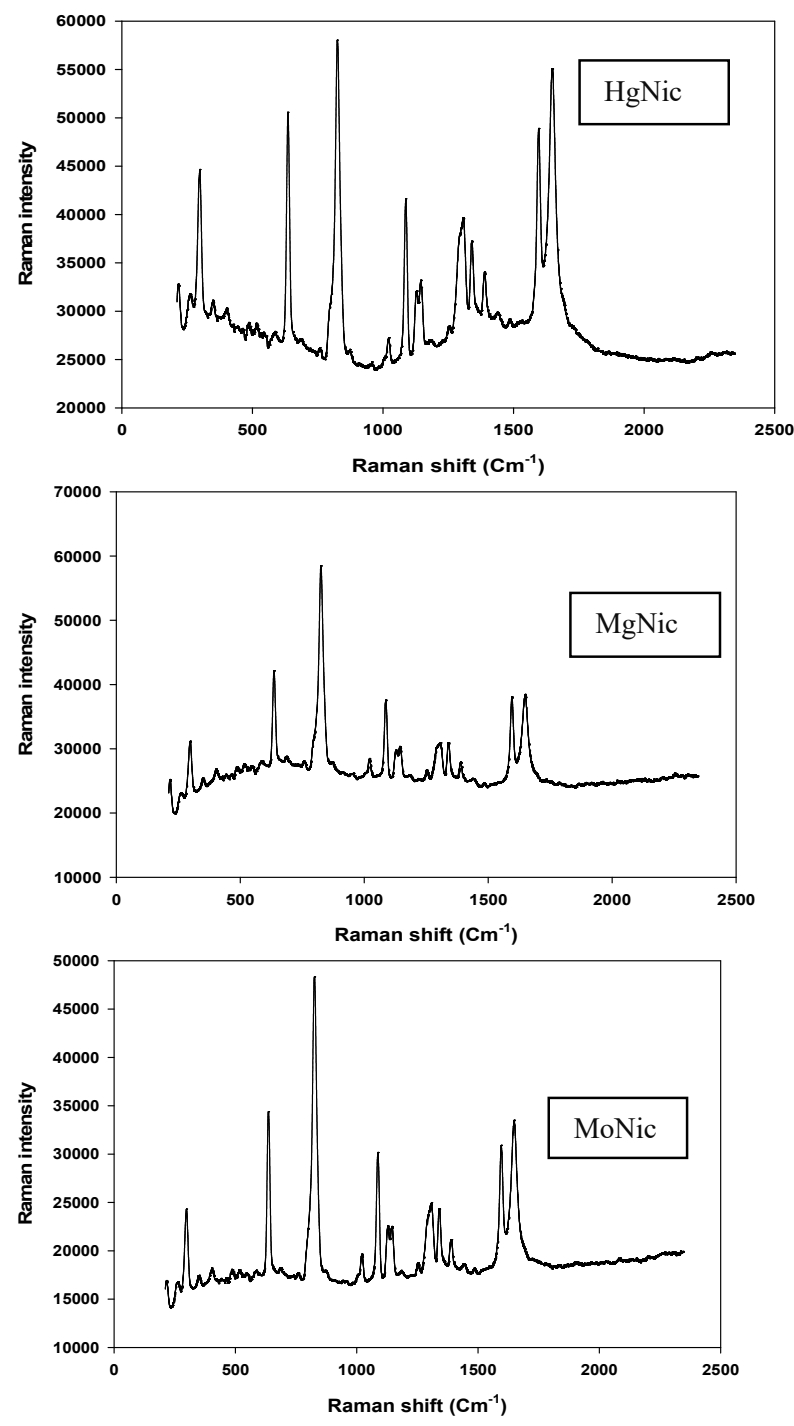

Figure 3. Raman spectral data of AlNic, HgNic, MgNic, and MoNic binary complexes. 

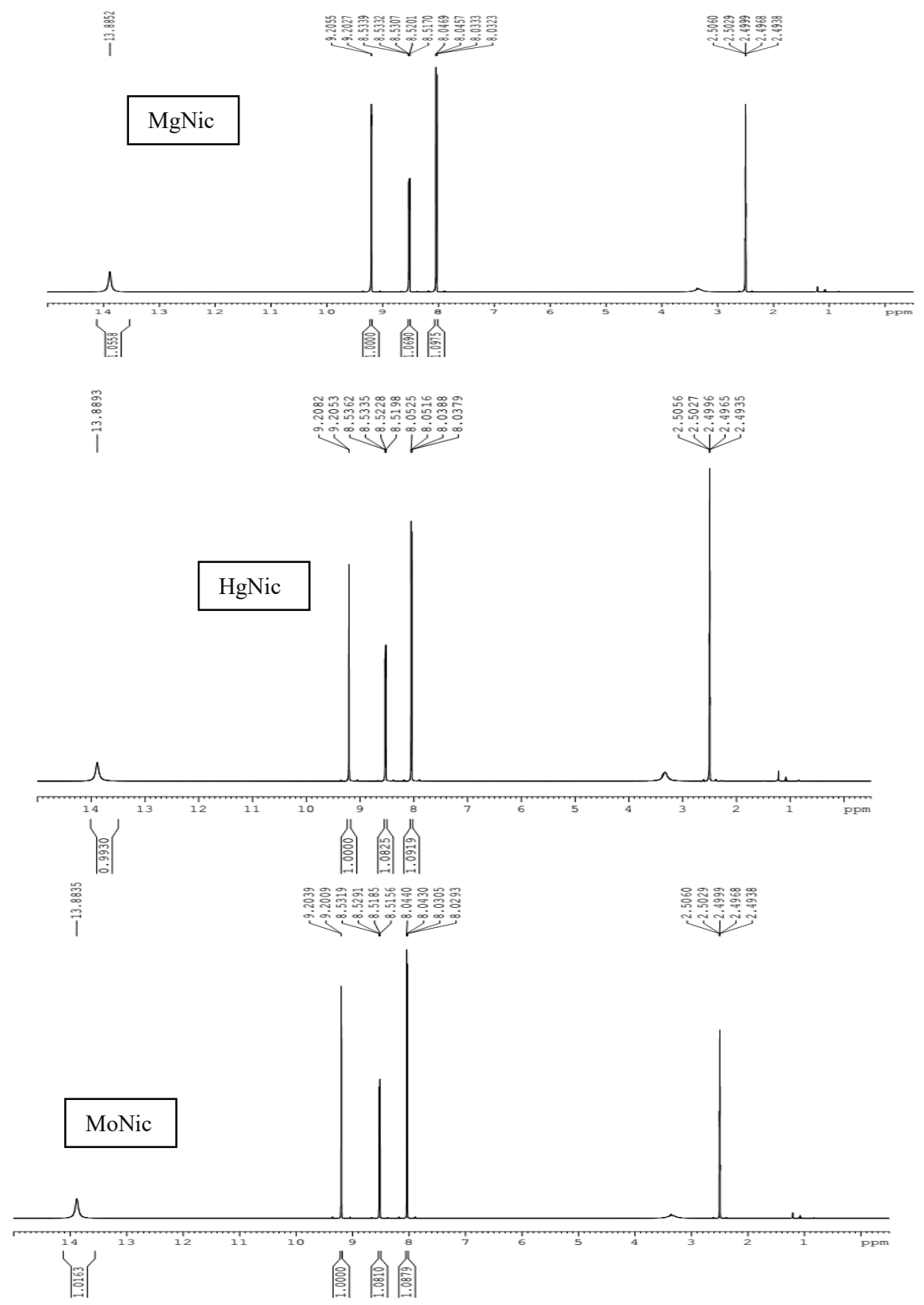

Bull. Chem. Soc. Ethiop. 2020, 34(3) 


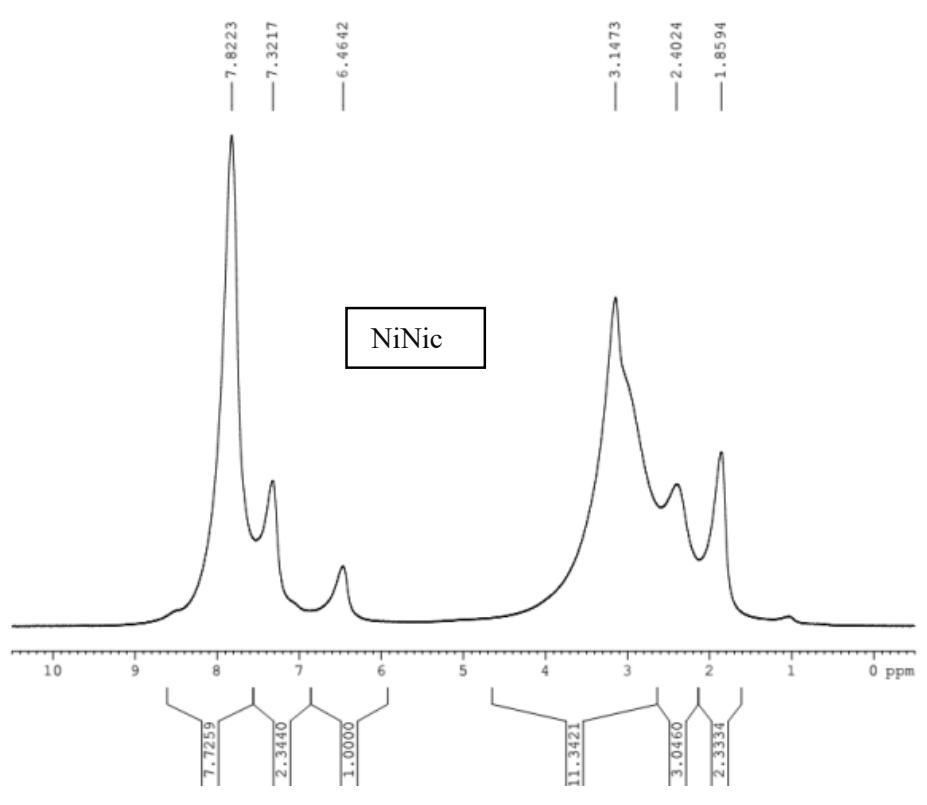

Figure 4. ${ }^{1} \mathrm{H}$ NMR spectral data of MgNIC, HgNIC, MoNIC, and NiNIC binary complexes.

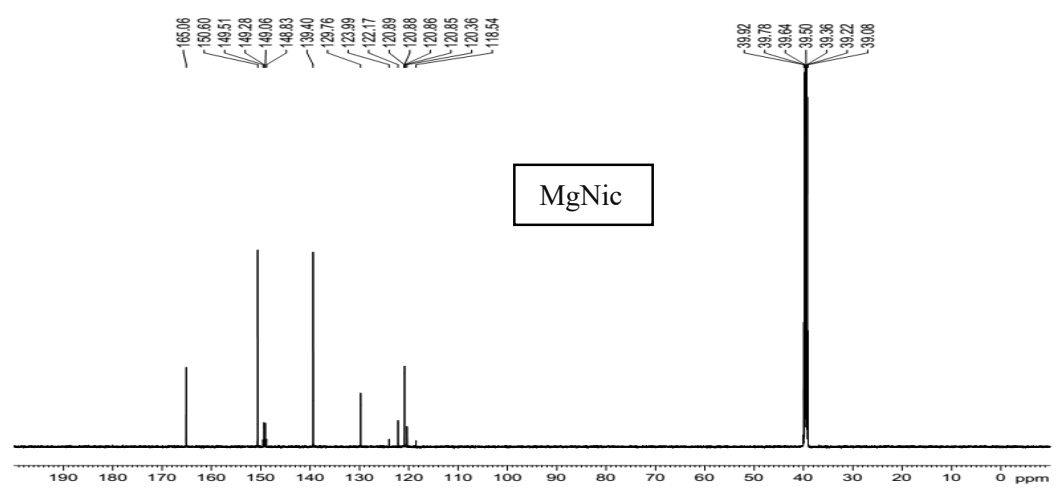



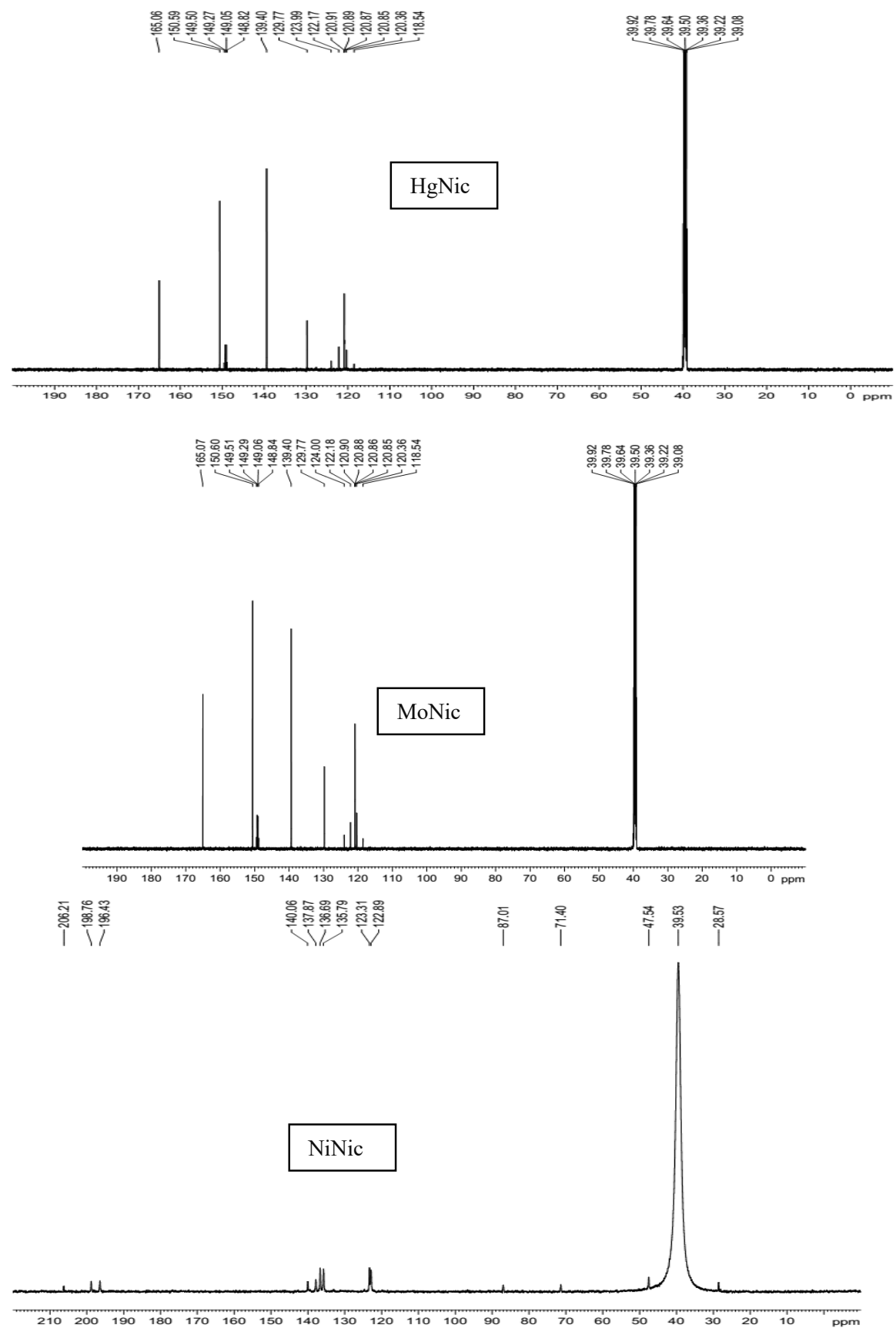

Figure $5 .{ }^{13} \mathrm{C}$ NMR spectral data of MgNIC, HgNIC, MoNIC, and NiNIC binary complexes.

Bull. Chem. Soc. Ethiop. 2020, 34(3) 


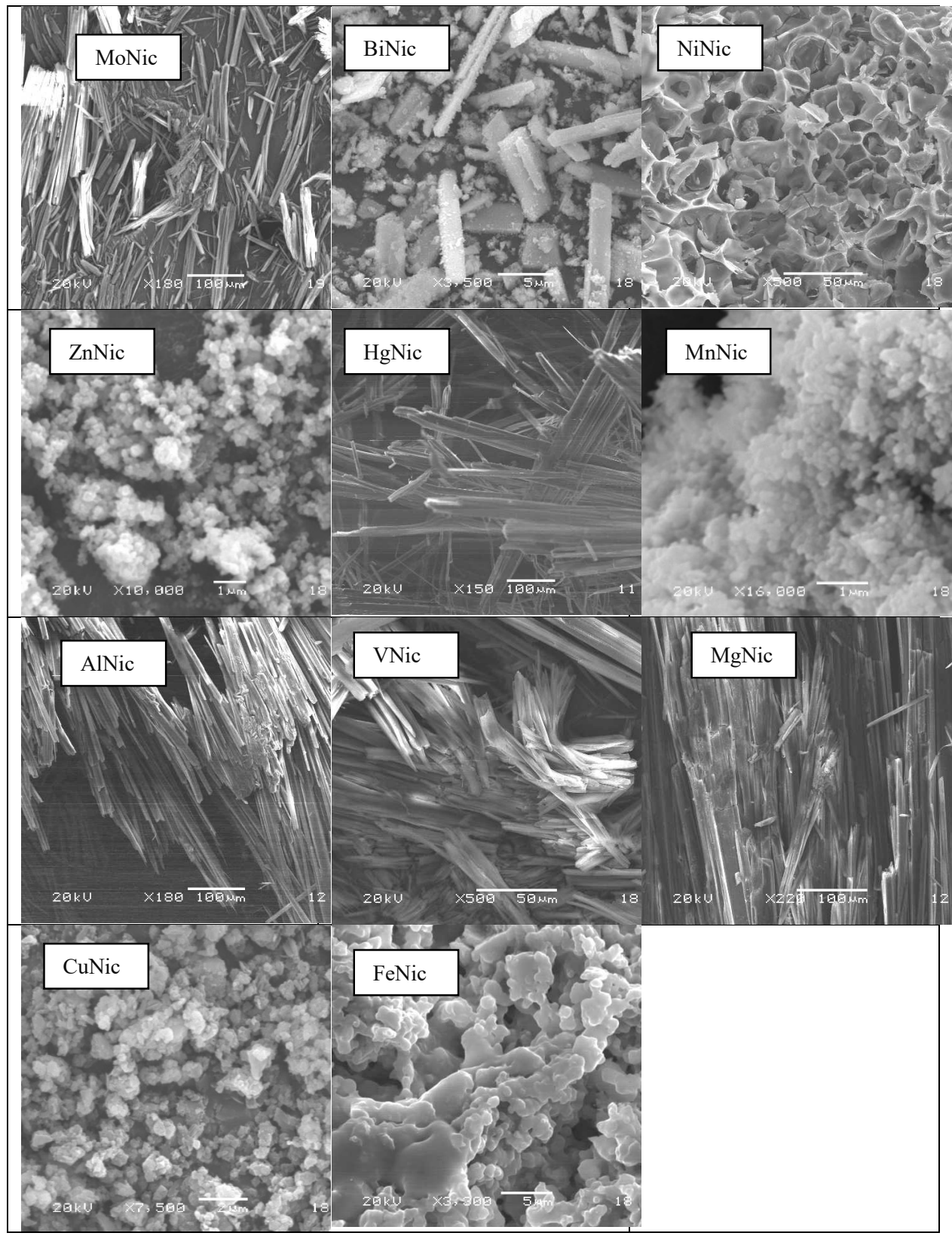

Figure 6. SEM images of MoNic, BiNic, NiNic, ZnNic, HgNic, MnNic, AlNic, VNic, MgNic, CuNic, FeNic binary complexes. 
Thermogravimetric analysis

Thermogravimetric analyses of the synthesized nicotine complexes were conducted in from 30 to $600{ }^{\circ} \mathrm{C}$. The thermograms are shown in Figure 7. The initial mass loss which was observed until $200{ }^{\circ} \mathrm{C}$ corresponds to the loss of water and ethanol molecules. For most of the synthesized metal-nicotine complexes, the mass loss from 220 to $310{ }^{\circ} \mathrm{C}$ corresponds to decomposition of ligand NIC thus residue at above $380{ }^{\circ} \mathrm{C}$ corresponds to metal-oxide.
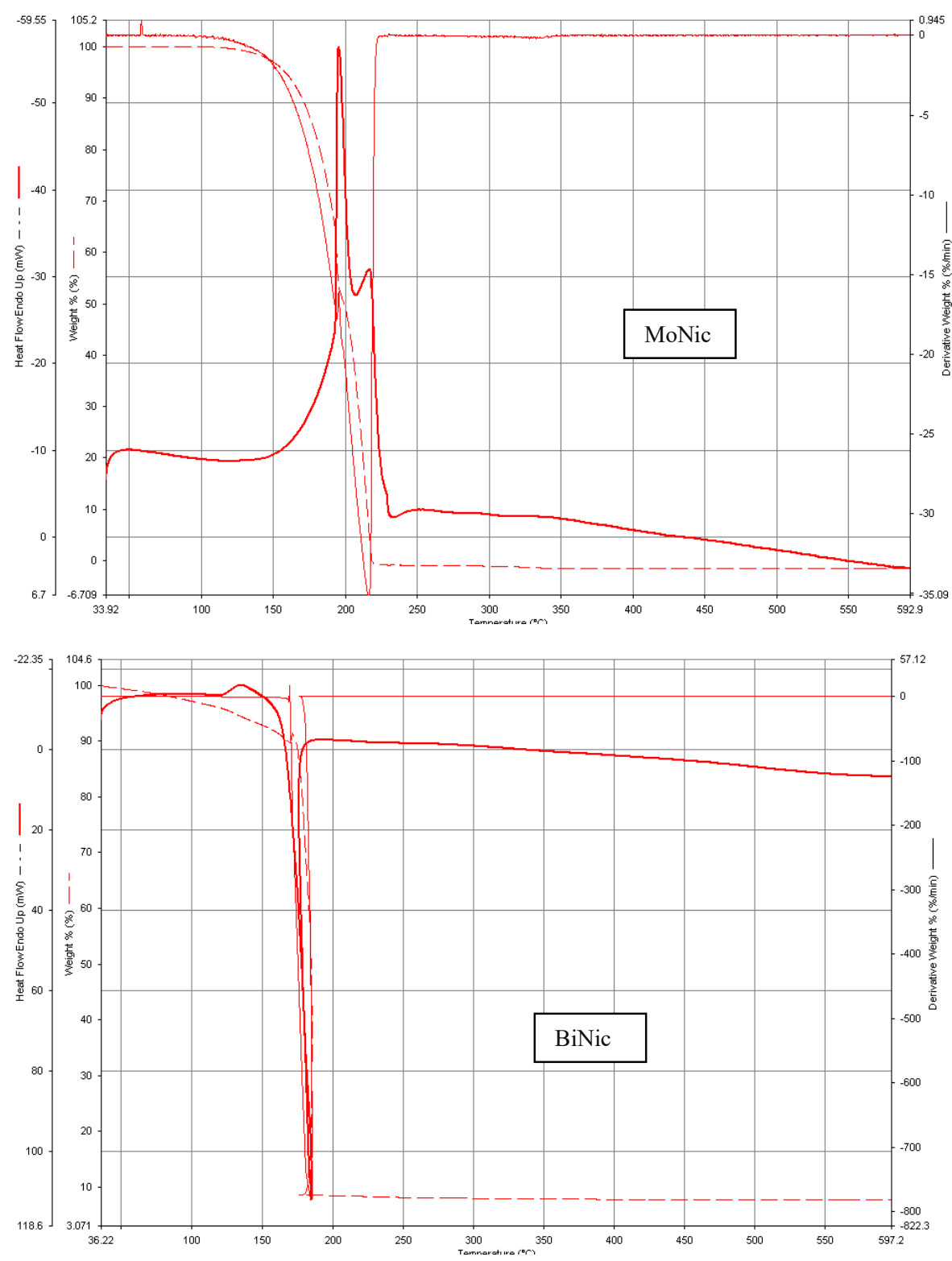

Bull. Chem. Soc. Ethiop. 2020, 34(3) 

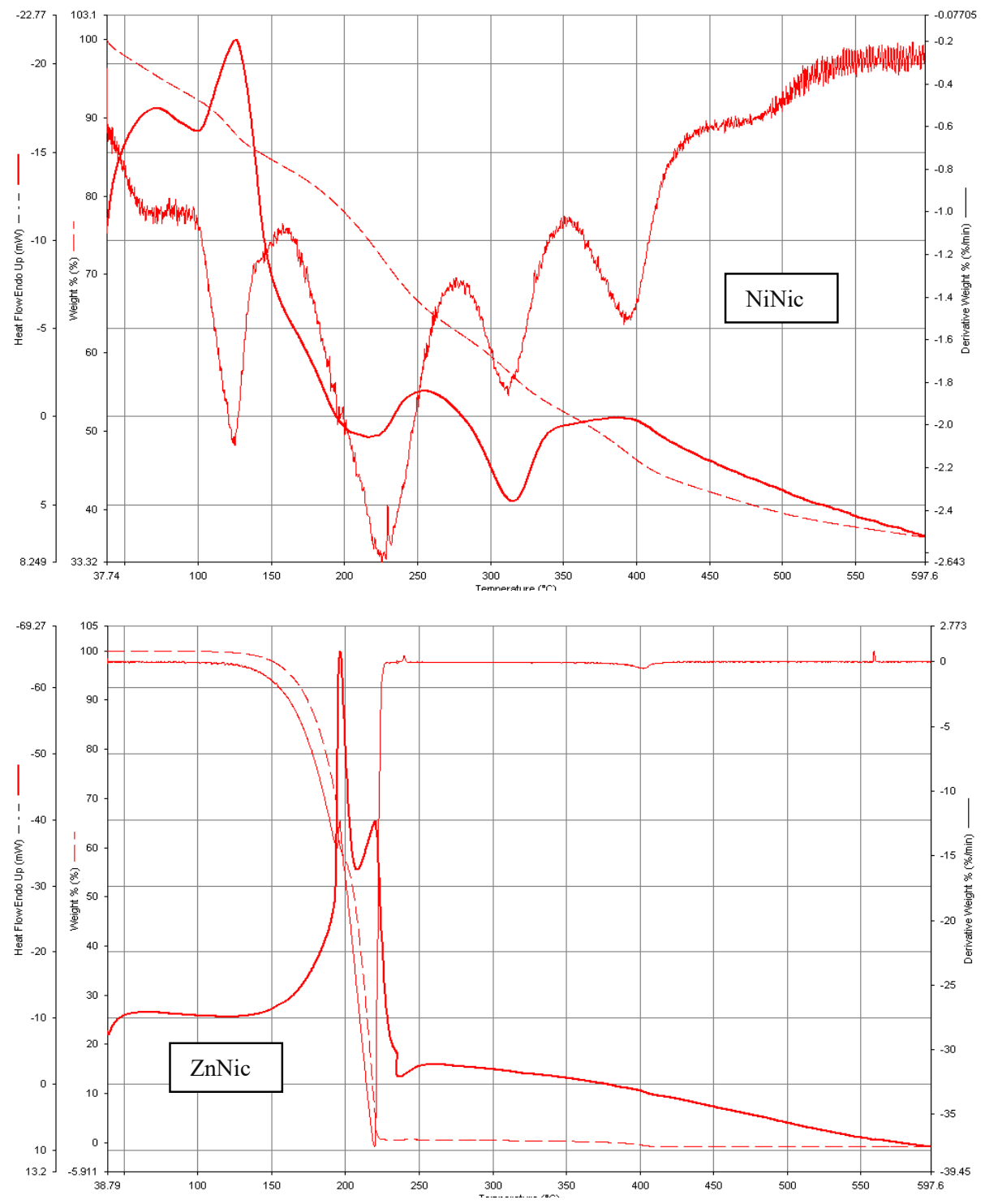

Bull. Chem. Soc. Ethiop. 2020, 34(3) 

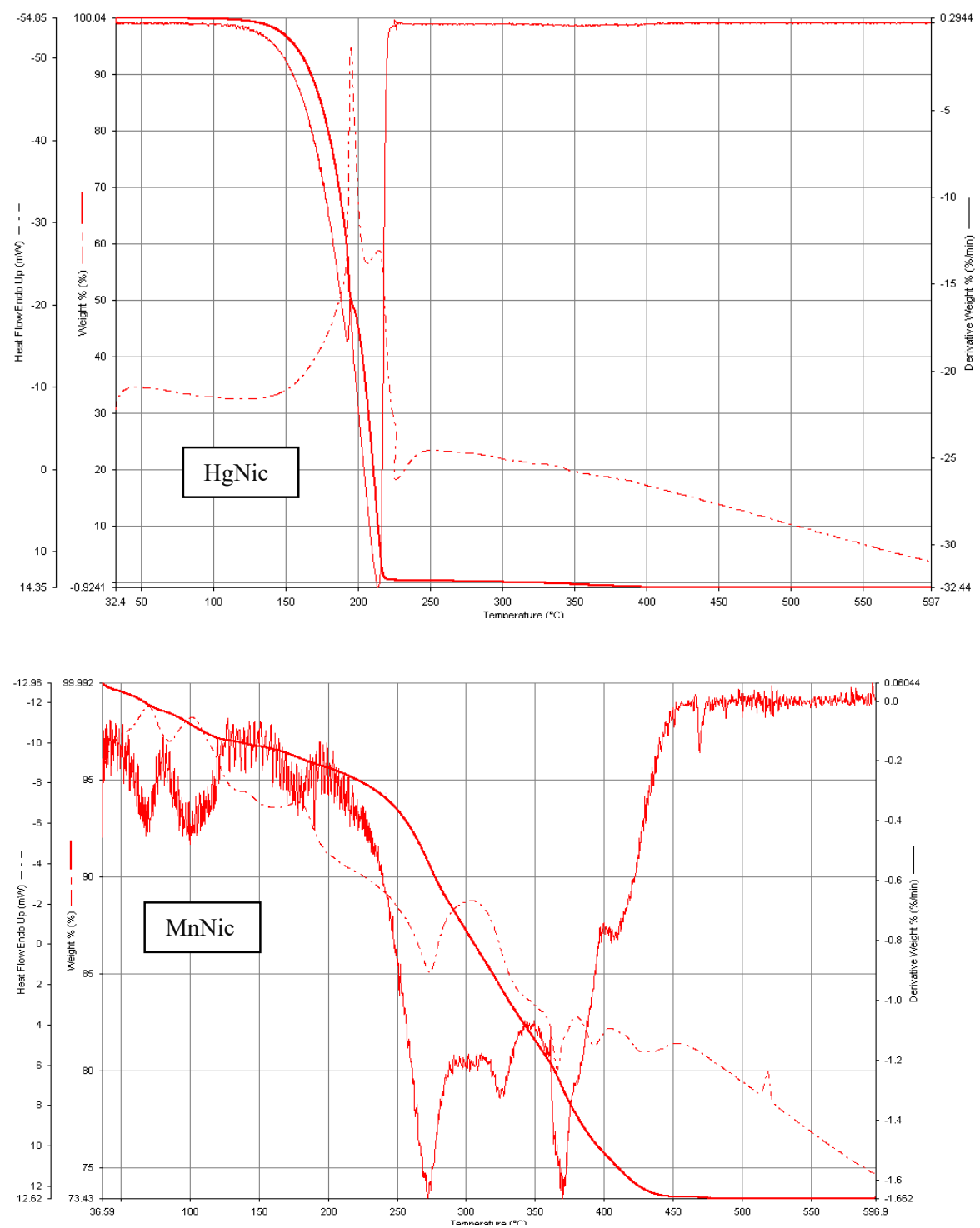

Figure 7. Thermograms of MoNic, BiNic, NiNic, ZnNic, HgNic, and MnNic, binary complexes.

Cytotoxicity's of nicotine and its metal complexes

When nicotine enters the body, it is distributed quickly through blood stream and crosses the blood-brain barrier reaching the brain within 10-20 s after inhalation. The elimination half-life of nicotine in the body is around two hours. The amount of nicotine absorbed by the body from smoking may depend on many factors, including the types of tobacco, whether the smoke is inhaled, and whether a filter is used. However, it has been found that the nicotine yield of 
individual products has only a small effect $(4.4 \%)$ on the blood concentration of nicotine suggesting "the assumed health advantage of switching to lower-tar and lower-nicotine cigarettes may be largely offset by the tendency of smokers to compensate by increasing inhalation". Nicotine is metabolized in liver by cytochrome P450 enzymes (mostly CYP2A6, and also by CYP2B6). A major metabolite is cotinine. Other primary metabolites include nicotine $\mathrm{N}$-oxide, nornicotine, nicotine isomethonium ion, 2-hydroxynicotine and nicotine glucuronide under some conditions. Glucuronidation and oxidative metabolism of nicotine to cotinine are both inhibited by menthol, an additive to mentholated cigarettes, thus increasing the half-life of nicotine in vivo. Nicotine as a biomarker is very important for quantifying human exposure to environmental tobacco smoke (ETS) and for predicting potential health risks for exposed individuals. Passive smoking is a real and significant threat to public health. The first step is the promotion of effective measures protecting from indoor exposure to tobacco smoke at the workplace, in public transport, and other public places. In the same manner, as stated before, almost all nitrogen and oxygen donor ligands showed a lot of significant biological applications. In the present work, we examined the cytotoxicity's of nicotine and their binary complexes with molybdenum(IV), bismuth(III), nickel(II), zinc(II), mercury(II), manganese(II), aluminum(III), vanadium(V), magnesium(II), and copper(II) metal ions against: HepG2 (human hepatocellular carcinoma), HPC3 (human prostate cancer), and HCT116 (human colorectal carcinoma) tumor cell lines. From the results obtained (Table 1), it is possible to conclude that the complexes studied (under physiological conditions), namely, the nature of nicotine ligand (e.g., the number of $\mathrm{N}$ atoms), the characteristics of the leaving groups at some metal ions, the number and coordination mode of the metal ions, and their chemical environment, determine their bioactivities, most probably through induction of DNA structural rearrangements. Thus, the design of new, more effective bioactive drugs should be governed by these crucial factors, since slight changes in the metal coordination are sufficient to significantly change the in vitro antiproliferative and/ or cytotoxic properties of these complexes. Among the complex species tested against the three human cancer cell lines, i.e.:HepG2 (human hepatocellular carcinoma), HPC3 (human prostate cancer), and HCT116 (human colorectal carcinoma) tumor cell lines (Table 1), it was observed that: (i) The nicotine complexes involving molybdenum(IV), bismuth(III), nickel(II), manganese(II), and magnesium(II) metal ions showed very strong cytotoxic activities against HepG2, HPC3, and HCT116 tumor cell lines. (ii) The nicotine complexes of nickel(II), mercury(II), and copper(II) metal ions showed weak activities against HepG2 , HPC3 , and HCT116 tumor cell lines. (iii) Zinc(II), and vanadium(V) complexes of nicotine exhibited weak cytotoxic activities, while manganese(II), and aluminum(III) complexes of nicotine exhibited a moderate activity against HepG2 cancer cell line. (iv) Zinc(II), and magnesium(II) complexes of nicotine exhibited a strong activity against HPC3 cancer cell line. (v) Aluminum(III), vanadium(V) and copper(II) complexes of nicotine exhibited a very weak activity against HPC3 cancer cell line. (vi) Aluminum(III), vanadium(V) and zinc(II) complexes of nicotine exhibited moderate activities against HCT116 tumor cell line.

\section{Antioxidant activities of the synthesized nicotine metal complexes}

Antioxidant activity is one of the important standard assays in pharmaceutical to examine the potency of a compound to inhibit the formation of free radical. 2,2-Diphenyl-1-picrylhydrazyl (DPPH) is a popular "stable free-radical" for antioxidant assay. DPPH has an unpaired electron at one atom of Nitrogen Bridge. It was known that, nicotine (Nic) displays numerous pharmacological and therapeutic applications, as well, metal ions play a crucial role in various enzymes that catalyze oxidation/reduction reactions correlated with the antioxidant system of the organism concerned. However, the different behavior depends upon the chemical environment and the nature of the chelating agent. In the present work, molybdenum(IV), bismuth(III), nickel(II), zinc(II), mercury(II), manganese(II), aluminum(III), vanadium(V), 
magnesium(II), and copper(II) metal-nicotine complexes were subjected to DPPH radical scavenging measurements (Table 2). By looking at the data listed in Table 2, we can conclude that most metal nicotine complexes displayed a moderate antioxidant activity.

Table 1. Cytotoxicity of nicotine ligand (NIC) metal complexes.

\begin{tabular}{|l|c|c|c|}
\hline \multirow{2}{*}{$\begin{array}{l}\text { Nicotine } \\
\text { complexes }\end{array}$} & \multicolumn{3}{|c|}{ Cancer cell line $^{a} / \mathrm{IC}_{50}(\mu \mathrm{g} / \mathrm{mL})^{b}$} \\
\hline & HEPG-2 & HPC3 & HCT116 \\
\hline MoNic & $0.0162 \pm 0.005$ & $0.361 \pm 0.054$ & $0.355 \pm 0.052$ \\
\hline BiNic & $0.0279 \pm 0.006$ & $0.034 \pm 0.006$ & $0.0884 \pm 0.001$ \\
\hline NiNic & $227.48 \pm 13.124$ & $83.87 \pm 7.679$ & $127.4112 \pm 11.21$ \\
\hline ZnNic & $32.954 \pm 3.454$ & $0.1143 \pm 0.007$ & $2.4004 \pm 0.410$ \\
\hline HgNic & $80.42 \pm 5.460$ & $62.23 \pm 6.176$ & $36.65 \pm 5.654$ \\
\hline MnNic & $2.125 \pm 0.254$ & $1.200 \pm 0.012$ & $0.8915 \pm 0.100$ \\
\hline AlNic & $7.503 \pm 1.464$ & $56.91 \pm 7.665$ & $6.524 \pm 1.740$ \\
\hline VNic & $28.47 \pm 2.604$ & $53.66 \pm 5.156$ & $1.66 \pm 0.188$ \\
\hline MgNic & $0.104 \pm 0.034$ & $0.0104 \pm 0.006$ & $0.0121 \pm 0.004$ \\
\hline CuNic & $14.532 \pm 0.124$ & $3009.03 \pm 54.543$ & $28.656 \pm 4.016$ \\
\hline
\end{tabular}

${ }^{a} \mathrm{The}_{\mathrm{IC}} \mathrm{IC}_{50}$ value is the molarity at which $50 \%$ of tumor cell death was observed after $72 \mathrm{~h}$ under standard tissue culture conditions. Each experimental variable was run three times, and the results were expressed via mean value and standard deviation. A two-tailed $p$ value of less than 0.05 was considered to be statistically significant. ${ }^{b}$ Cancer cell lines: HepG2 (human hepatocellular carcinoma), HPC3 (human prostate cancer), and HCT116 (human colorectal carcinoma) tumor cell lines.

Table 2. DPPH radical scavenging assay of nicotine metal complexes.

\begin{tabular}{|l|c|}
\hline Nicotine complexes & DPPH inhibition (\%) \\
\hline MoNic & $57.6 \pm 3.5$ \\
\hline BiNic & $35.5 \pm 3.6$ \\
\hline NiNic & $51.3 \pm 2.3$ \\
\hline ZnNic & $68.6 \pm 2.4$ \\
\hline HgNic & $44.7 \pm 2.3$ \\
\hline MnNic & $45.5 \pm 3.5$ \\
\hline AlNic & $23.6 \pm 4.1$ \\
\hline VNic & $56.4 \pm 3.8$ \\
\hline MgNic & $53.6 \pm 3.2$ \\
\hline CuNic & $34.2 \pm 2.2$ \\
\hline
\end{tabular}

Microbial growth inhibitory activities of the synthesized nicotine metal complexes

Antimicrobial assays against several microorganisms such as Escherichia coli, Staphylococcus aureus, Bacillus subtilis, and Candida albicansis are usually conducted to examine the antimicrobial potency of the complex. In this study, the antimicrobial assay was done against $E$. coli (gram-negative) and $S$. aureus (gram-positive). Severe E. coli infection may causes bloody diarrhea leading to kidney failure, while $S$. aureus infection especially in the bloodstream may lead to sepsis (life-threatening low blood pressure) [43]. Microbial growth inhibitory activity or antimicrobial activity of nicotine and its metal complexes were studied against the Escherichia coli and Staphylococcus aureus by broth macro dilution method in lysogeny broth media. Commercial antibiotic ampicillin was used as the standard reference. From the data shown in Table 3, Nic was shown to have a moderate antimicrobial activity against the two tested bacteria. Such outcome is probably due to the structure of the ligand NIC that is consists of nitrogen atoms which act as the nutrient source for the bacteria. 
For the synthesized complexes, some exhibited smaller antimicrobial activity than that of the ligand. Antimicrobial activities of the synthesized binary nicotine complexes are given in Table 3. Antimicrobial activity of the complexes follows the order: Zinc $>$ nickel $>$ copper $>$ magnesium $>$ molybdenum $>$ aluminum $>$ vanadium $>$ mercury $>$ bismuth. It is worthwhile to diagnose the efficacy of molybdenum nicotine complex by determining the MIC (minimum inhibitory concentration) which is the lowest concentration of an antimicrobial agent that is able to inhibit the visible growth of a microorganism after overnight incubation [44].

Table 3. Antimicrobial activity of the synthesized binary complexes.

\begin{tabular}{|c|c|c|c|c|c|c|c|}
\hline \multirow{3}{*}{$\begin{array}{l}\text { Complex species } \\
\text { Ampicilin } \\
\text { (Standard control) }\end{array}$} & \multirow{3}{*}{$\begin{array}{l}\text { Concentration } \\
(\mu \mathrm{g} / \mathrm{mL}) \\
100\end{array}$} & \multicolumn{6}{|c|}{ \%Inhibition \pm SD } \\
\hline & & \multicolumn{3}{|c|}{ E. coli } & \multicolumn{3}{|c|}{ S. aureus } \\
\hline & & 59.8 & \pm & 2.0 & 99.3 & \pm & 0.1 \\
\hline & 1000 & 99.6 & \pm & 0.1 & 99.7 & \pm & 0.0 \\
\hline & 2000 & 100.0 & \pm & 0.0 & 100.0 & \pm & 0.0 \\
\hline \multirow[t]{3}{*}{$\mathrm{Nic}$} & 100 & 12.3 & \pm & 0.1 & 14.5 & \pm & 1.5 \\
\hline & 1000 & 43.1 & \pm & 2.4 & 38.5 & \pm & 2.8 \\
\hline & 2000 & 57.7 & \pm & 3.6 & 61.3 & \pm & 1.2 \\
\hline \multirow[t]{3}{*}{ MoNic } & 100 & 14.8 & \pm & 1.2 & 17.5 & \pm & 1.8 \\
\hline & 1000 & 23.6 & \pm & 1.3 & 22.4 & \pm & 3.0 \\
\hline & 2000 & 61.1 & \pm & 3.9 & 66.7 & \pm & 3.1 \\
\hline \multirow[t]{3}{*}{$\mathrm{BiNic}$} & 100 & 13.1 & \pm & 1.6 & 12.5 & \pm & 1.7 \\
\hline & 1000 & 19.4 & \pm & 2.2 & 25.9 & \pm & 2.3 \\
\hline & 2000 & 49.6 & \pm & 3.1 & 49.3 & \pm & 3.1 \\
\hline \multirow[t]{3}{*}{ NiNic } & 100 & 23.6 & \pm & 1.3 & 34.2 & \pm & 1.1 \\
\hline & 1000 & 65.5 & \pm & 1.8 & 45.6 & \pm & 4.6 \\
\hline & 2000 & 76.6 & \pm & 2.2 & 73.7 & \pm & 4.3 \\
\hline \multirow[t]{3}{*}{ ZnNic } & 100 & 39.8 & \pm & 1.2 & 33.5 & \pm & 1.3 \\
\hline & 1000 & 56.3 & \pm & 3.5 & 53.8 & \pm & 1.6 \\
\hline & 2000 & 91.2 & \pm & 6.2 & 83.9 & \pm & 3.8 \\
\hline \multirow[t]{3}{*}{$\mathrm{HgNic}$} & 100 & 12.0 & \pm & 1.3 & 21.2 & \pm & 1.8 \\
\hline & 1000 & 43.5 & \pm & 2.2 & 36.4 & \pm & 2.5 \\
\hline & 2000 & 55.9 & \pm & 3.6 & 46.7 & \pm & 3.5 \\
\hline \multirow[t]{3}{*}{ AlNic } & 100 & 23.1 & \pm & 1.8 & 21.5 & \pm & 1.7 \\
\hline & 1000 & 42.4 & \pm & 2.6 & 37.9 & \pm & 3.4 \\
\hline & 2000 & 69.6 & \pm & 3.1 & 55.3 & \pm & 6.1 \\
\hline \multirow[t]{3}{*}{ VNic } & 100 & 21.6 & \pm & 2.1 & 19.2 & \pm & 1.1 \\
\hline & 1000 & 35.5 & \pm & 3.0 & 25.4 & \pm & 2.6 \\
\hline & 2000 & 66.6 & \pm & 3.2 & 54.7 & \pm & 3.3 \\
\hline \multirow[t]{3}{*}{ MgNic } & 100 & 23.6 & \pm & 2.1 & 21.2 & \pm & 2.1 \\
\hline & 1000 & 35.5 & \pm & 0.8 & 35.4 & \pm & 3.6 \\
\hline & 2000 & 66.6 & \pm & 1.2 & 63.7 & \pm & 4.3 \\
\hline \multirow[t]{3}{*}{ CuNic } & 100 & 16.6 & \pm & 1.1 & 13.2 & \pm & 1.1 \\
\hline & 1000 & 38.5 & \pm & 2.8 & 35.8 & \pm & 2.6 \\
\hline & 2000 & 75.6 & \pm & 4.2 & 73.9 & \pm & 3.3 \\
\hline
\end{tabular}

In this work, minimum compound concentrations that inhibited $50 \%\left(\mathrm{MIC}_{50}\right)$ and $90 \%$ $\left(\mathrm{MIC}_{90}\right)$ of the bacteria were determined. MICs of ligand NIC, and its zinc complex were determined and the results are shown in Table 4. Complexes of zinc showed higher inhibition activity than that of ligand Nic alone (especially against gram positive bacteria, S. aureus) as shown by smaller $\mathrm{MIC}_{50}$ and $\mathrm{MIC}_{90}$ values. The Nic complexes were found to be more effective toward gram positive bacteria than to gram negative bacteria, possibly due to difference in their cell walls $[45,46]$. As gram positive bacteria, S. aureus cell wall consists of thick peptidoglycan 
layer and plasma membrane; as gram negative bacteria, $E$. coli cell wall possesses an extra layer (outer membrane layer) which is high in lipid. This lipid containing membrane limits the ability of the chelate complex to permeate into the bacteria inner membrane thus lowering the inhibition activity.

Table 4. MIC $(\mu \mathrm{g} / \mathrm{mL})$ of the tested compounds.

\begin{tabular}{|l|c|c|c|c|c|}
\hline Compound & \multicolumn{2}{|c|}{ E. coli } & \multicolumn{2}{c|}{ S. aureus } \\
\hline & $\mathrm{MIC}_{50}$ & $\mathrm{MIC}_{90}$ & $\mathrm{MIC}_{50}$ & $\mathrm{MIC}_{90}$ \\
\hline Ampicilin & 4.4 & 52.3 & & 0.5 & 2.9 \\
\hline Nic & $>2000$ & $>2000$ & $>2000$ & $>2000$ \\
\hline ZnNic & 705.8 & 873.5 & 342.3 & 498.6 \\
\hline
\end{tabular}

\section{CONCLUSION}

The synthesis of the complexes between nicotine and essential metal ions were studied to investigate the complexation behavior of these systems as it could mimic many biological interactions of the. The complexes appear to be superior in biological properties to ligand alone. The complete elucidation molecular structures of the synthesized binary nicotine complexes were confirmed by detailed spectroscopic IR, Raman, NMR, and SEM techniques. The complexes were found to increase the cytotoxic, antioxidant, and antimicrobial activity of the pure ligand which is probably related to the enhancement of hydrophobicity of the synthesized compounds.

\section{ACKNOWLEDGMENTS}

The authors extend their appreciation to the Deanship of Scientific Research at King Khalid University for supporting this work through research groups program under grant number R.G.P 2/106/41.

\section{REFERENCES}

1. Benowitz, N.L.; Hukkanen, J.; Jacob, P. Nicotine chemistry, metabolism, kinetics and biomarkers. Handbook Exp. Pharmacol. 2009, 192, 29-60.

2. Miller, N.S.; Cocores, J.A. Nicotine dependence: Diagnosis, chemistry, and pharmacologic treatments. Pediatr. Rev. 1993, 14, 275-279.

3. Miller, N.S.; Cocores, J.A.; Belkin, B. Nicotine dependence: Diagnosis, chemistry and pharmacological treatments. Ann. Clin. Psychiatry 1991, 3, 47-53.

4. McKinney, D.L.; Vansickel, A.R. Nicotine chemistry, pharmacology, and pharmacokinetics. Neuropathol. Drug Addictions Substance Misuse 2016, 1, 93-103.

5. Smith, C.R. Complex metal-nicotine compounds. J. Am. Chem. Soc. 1953, 75, 2010-2012.

6. Schmidt, B.; Neitemeier, V. 6-Pyridylnicotineand bis-6,6'-nicotine - new chiral 2,2'bipyridines. Synthesis 1998, 1, 42-44.

7. Damaj, M.I.; Glassco, W.; Dukat, M.; Martin, B.R. Pharmacological characterization of nicotine-induced seizures in mice. J. Pharmacol. Exp. Ther. 1999, 291, 1284-1291.

8. Flammia, D.; Dukat, M.; Damaj, M.I.; Martin, B.; Glennon, R.A. Lobeline. Structureaffinity investigation of nicotinic acetylcholinergic receptor binding. J. Med. Chem. 1999, 42, 3726-3731.

9. Damaj, M.I.; Fei-Yin, M.; Dukat, M.; Glassco, W.; Glennon, R.A.; Martin, B.R. Antinociceptive responses to nicotinic acetylcholine receptor ligands after systemic and intrathecal administration in mice. J. Pharmacol. Exp. Ther. 1998, 284, 1058-1065. 
10. Imad Damaj, M.; Glassco, W.; Dukat, M.; May, E.L.; Glennon, R.A.; Martin, B.R. Pharmacology of novel nicotinic analogs. Drug Dev. Res. 1996, 38, 177-187.

11. Roduit, J.-P.; Wellig, A.; Kiener, A. Renewable functionalized pyridines derived from microbial metabolites of the alkaloid (5)-nicotine. Heterocycles 1997, 45, 1687-1702.

12. Comins, D.L.; King, L.S.; Smith, E.D.; Février, F.C. Synthesis of C-4 substituted nicotine derivatives via an $\mathrm{N}$-acylpyridinium salt of (S)-nicotine. Org. Lett. 2005, 7, 5059-5062.

13. Taylor, E.C.; Boyer, N.E. Pyridine-1-oxides. IV. Nicotine-1-oxide, nicotine-1'-oxide, and nicotine-1,1'-dioxide. J. Org. Chem. 1959, 24, 275-277.

14. Youssif, S. Recent trends in the chemistry of pyridine N-oxide. Arkivoc 2001, 242-268.

15. Malczewska-Jaskóła K.; Jankowski W.; Warzajtis B.; Jasiewicz B.; Hoffmann M.; Rychlewska U. Chalcogenated (S)-(-)-nicotine derivatives as chiral linkers for 1D coordination polymers. Polyhedron 2015, 100, 404-411.

16. Jasiewicz B.; Hoffmann M.; Ga̧sowska A.; Jastrząb R.; Malczewska-Jaskóła K. Spectroscopic, potentiometric and quantum-mechanical studies of S-(-)-nicotine complexes with $\mathrm{Cu}(\mathrm{II})$ ion. Acta Chim. Slov. 2014, 61, 137-144.

17. Hirtenlehner, C.; Monkowius, U. Syntheses, crystal, structures and blue luminescence of $\mathrm{Cu}_{2} \mathrm{X} 2\left(\mathrm{Ph}_{3} \mathrm{P}\right)_{2}[(-) \text {-nicotine }]_{2}(\mathrm{X}=\mathrm{Br}, \mathrm{I})$. Inorg. Chem. Commun. 2012, 15, 109-112.

18. Jana, S.; Cormack, P.A.G.; Kennedy, A.R.; Sherrington, D.C. Synthesis of main chain chiral methacrylate copolymers via chirality transfer from polymerizable chiral metal complexes. J. Mater. Chem. 2009, 19, 3427-3442.

19. Uçar, I.; Karabulut, B.; Bulut, A.; Büyükgüngör, O. Crystal structure and EPR studies of binary complex of cobalt(II) with saccharin and ethylisonicotine. Spectrochim. Acta A Mol. Biomol. Spectrosc. 2008, 71, 1239-1245.

20. Escudero-Adán, E.C.; Benet-Buchholz, J.; Kleij, A.W. Supramolecular adsorption of alkaloids by metallosalphen complexes. Inorg. Chem. 2008, 47, 4256-4263.

21. Guan, J.; Fischer, R.D. Tris(indenyl)lanthanoid complexes ( $\mathrm{Ln}=\mathrm{La}, \mathrm{Pr}, \mathrm{Nd}$ ) containing either (S)-(-)-nicotine or two simpler pyridine bases. Eur. J. Inorg. Chem. 2001, 10, $2497-$ 2508.

22. Rusjan, M.; Chaia, Z.; Piro, O.E.; Guillon, D.; Cukiernik, F.D. Synthesis, structure and magnetic properties of tetrakis- $\mu$-carboxylatobis(dodecylnicotinato) dicopper(II) complexes; crystal and molecular structure of the decyl carboxylate derivative. Acta Crystallogr. B Struct. Sci. Cryst. 2000, 56, 666-672.

23. Schmidt, B.; Neitemeier, V. 6-Pyridylnicotine and bis-6,6'-nicotine - new chiral 2,2'bipyridines. Synthesis 1998, 1, 42-44.

24. Seeman, J.I. Recent studies on conformational analysis and steric effects. Pure Appl. Chem. 1987, 59, 1661-1672.

25. Maurya, R.C.; Shukla, R.; Gupta, D.C.; Shukla, R.K.; Anandam, N.; Malik, W.U. Synthesis and characterization of some new cyanonitrosyl complexes of chromium(I) with nicotine and related ligands. Synth. React. Inorg. Met.-Org. Nano-Metal Chem. 1986, 16, 1243-1252.

26. Albertí, F.M.; Fiol, J.J.; García-Raso, A.; Torres, M.; Terrón, A.; Barceló-Oliver, M.; Prieto, M.J.; Moreno, V.; Molins, E. Ruthenium(III) and iridium(III) complexes with nicotine. Polyhedron 2010, 29, 34-41.

27. Fazary, A.E.; Alshihri, A.S.; Alfaifi, M.Y.; Saleh, K.A.; Elbehairi, S.E.I.; Fawy, K.F.; AbdRabboh, H.S.M. Gibbs energies of protonation and complexation of platinum and vanadate metal ions with naringenin and phenolic acids: Theoretical calculations associated with experimental values. J. Chem. Thermodyn. 2016, 100, 7-21.

28. Fazary, A.E.; Al-Shihri, A.S.; Saleh, K.A.; Alfaifi, M.Y.; Alshehri, M.A. Elbehairi, S.E.I.: Di- and tri-valent metal ions interactions with four biodegradable hydroxamate and cataecholatesiderophores: New insights into their complexation equilibria. J. Sol. Chem. 2016, 45, 732-749. 
29. Fazary, A.E.; Ramadan, A.M. Stability constants and complex formation equilibria between iron, calcium, and zinc metal ions with vitamin B9 and glycine. Complex Met. 2014, 1, 139148.

30. Fazary, A.E.; Rajhi, A.Q. Complexation equilibria of vitamin B9, glycine oligopeptides with di- and trivalent metal ions. Asian J. Chem. 2015, 27, 3872-3876.

31. Fazary, A.E.: Metal complexes of salicylhydroxamic acid and 1,10-phen-anthroline; equilibrium and antimicrobial activity studies. Bull. Chem. Soc. Ehiop. 2014, 28, 393-402.

32. Rajhi, A.Y.; Ju, Y.-H.; Angkawijaya, A.E.; Fazary, A.E. Complex formation equilibria and molecular structure of divalent metal ions-vitamin B3-glycine oligopeptides systems. J. Sol. Chem. 2013, 42, 2409-2442.

33. Angkawijaya, A.E.; Fazary, A.E.; Ismadji, S.; Ju, Y.-H. Cu(II), Co(II), and Ni(II)antioxidativephenolate-glycine peptide systems: An insight into its equilibrium solution study. J. Chem. Eng. Data 2012, 57, 3443-3451.

34. Angkawijaya, A.E.; Fazary, A.E.; Hernowo, E.; Ismadji, S.; Ju, Y.-H. Nickel and cobalt complexes of non-protein L-norvaline and antioxidant ferulic acid: Potentiometric and spectrophotometric studies. J. Sol. Chem. 2012, 41, 1156-1164.

35. Hernowo, E.; Angkawijaya, A.E.; Fazary, A.E.; Ismadji, S.; Ju, Y.-H. Complex stability and molecular structure studies of divalent metal ion with L-norleucine and vitamin b3. J. Chem. Eng. Data 2011, 56, 4549-4555.

36. Fazary, A.E.; Hernowo, E.; Angkawijaya, A.E.; Chou, T.-C.; Lin, C.H.; Taha, M.; Ju, Y.-H. Complex formation between ferric(III), chromium(III), and cupric(II) metal ions and (O,N) and $(\mathrm{O}, \mathrm{O})$ donor ligands with biological relevance in aqueous solution. J. Sol. Chem. 2011, 40, 1965-1986.

37. Angkawijaya, A.E.; Fazary, A.E.; Hernowo, E.; Taha, M.; Ju, Y.-H. Iron(III), chromium(III), and copper(II) complexes of L-norvaline and ferulic acid. J. Chem. Eng. Data 2011, 56, 532-540.

38. Fazary, A.E.; Taha, M.; Ju, Y.-H. Iron complexation studies of gallic acid. J. Chem. Eng. Data 2009, 54, 35-42.

39. Khalil, M.M.; Fazary, A.E. Potentiometric studies on binary and ternary complexes of diand trivalent metal ions involving some hydroxamic acids, amino acids, and nucleic acid components. Monatsh Chem. 2004, 135, 1455-1474.

40. Fazary, A.E.; Fawy, K.F.; Bani-Fwaz, M.Z.; Sahlabji, T.; Abd-Rabboh, H.S.M. Thermodynamic studies on metal ions - ninhydrin - glycine interactions in aqueous solutions. J. Chem. Thermodyn. 2018, 118, 302-318.

41. Fazary, A.E.; Bani-Fwaz, M.Z.; Fawy, K.F.; Abd-Rabboh, H.S.M. Levaquin drug complexing property towards platinum and palladium metal ions: Thermodynamic studies in aqueous solutions. J. Mol. Liquids 2018, 253C, 178-187.

42. Fazary, A.E.; ,Ju, Y.-H.; Fawy, K.F.; Al-Shihri, A.S.; Bani-Fwaz, M.Z.; Alfaifi, M.Y.; Shati, A.A.; Elbehairi, S.I.; Abd-Rabboh, H.S.M. Nicotine - metal ion interactions in solutions: Potentiometric, cyclic voltammetry investigations and quantum chemical calculations. $J$. Chem. Thermodyn. 2017, 112, 283-292.

43. Mayoclinic, Diseases and Conditions, U.S. National Library of Medicine, Department of Health and Human Services, Bethesda, 2014.

44. Davison, H.C.; Woolhouse, M.E.J.; Low, J.C. What is antibiotic resistance and how can we measure it?. Trends. Microbiol. 2000, 8, 554-559.

45. Atmaca, S.; Gul, K.; Cicek, R. The effect of zinc on microbial growth. Tr. J. Med. Sci. 1998, 28, 595-597.

46. Popova, T.P.; Alexandrova, R.I.; Tudose, R.; Mosoarca, E.M.; Costisor, O. Antimicrobial activity in vitro of four nickel complexes. Bulg. J. Agric. Sci. 2012, 18, 446-450. 